\title{
Revelation of $\beta$-sitosterol from Benincasa hispida Seeds, Carissa congesta Roots and Polyalthia longifolia Leaves by High Performance Liquid Chromatography
}

\author{
Gaurav Mahesh Doshi ${ }^{1}{ }^{*}$, Pratip Kashinath Chaskar ${ }^{1}$, Hemant Devidas Une ${ }^{2}$ \\ 'Department of Pharmacology and Pharmaceutical Chemistry, Vivekanand Education Society's College of Pharmacy, Mumbai, INDIA. \\ 2Department of Pharmacology, Y. B. Chavan College of Pharmacy, Rouzabagh, Aurangabad, Maharashtra, INDIA.
}

\begin{abstract}
Background: Fruit juice of Benincasa hispida $(\mathrm{BH})$ is regarded as Vrindamadhava that is recommended for internal use in snake's bites. The fruits have been reported to contain good amount of proteins, enzymes, Vitamin $\mathrm{B}_{1}$ and $\mathrm{C}$, flavonoid $\mathrm{C}$-glycoside, terpenes, phenolic acids and free sugars such as glucose, rhamnose, mannitol, uronic acid, astilbin, catechin, naringenin, pectic polysaccharides and even some trace metals. Polyalthia longifolia (PL) has been well known for its ayurvedic preparations such as Sitaphala kula, Kaphapitashama, Anulomak and Krimighna. PL leaves has been reported to contain phytoconstituents like polylongine, Aporphine- $N$ oxide alkaloids, allo-aromadendrene, caryophyllene oxide, $\beta$-caryophyllene, $\beta$-selinene, $\alpha$-humulene, $\alpha$-pinene and camphene. Carissa congesta (CC), known as Bengal currant, have yielded 2-acetyl phenol, carissone, carindone and Des-n-methylnoracronycine. $\beta$-sitosterol, an important phytoconstituent recognized from all these selected plants has been well known for its ethnopharmacological importance. In this new study, the research team members has focused on determining the percentage of the $\beta$-sitosterol present in the $\mathrm{BH}$ seeds, $\mathrm{CC}$ roots and PL leaves by subjecting the ex-
\end{abstract}

tract to High Performance Liquid Chromatography (HPLC). Materials and Methods: $\mathrm{BH}, \mathrm{CC}$ and PL plants were shade-dried and extracted by suitable extraction methods. In HPLC, peaks obtained in the extracts were compared with the standard by matching their retention time. Results: The amounts of $\beta$-sitosterol present in the $\mathrm{BH}$ seeds, $\mathrm{CC}$ roots and $\mathrm{PL}$ leaves extracts obtained at $254 \mathrm{~nm}$ were found to be $36.00,7.46$ and $3.21 \% \mathrm{w} / \mathrm{w}$ respectively. Conclusion: Thus, $\mathrm{BH}, \mathrm{PL}$ and $\mathrm{CC}$ extracts were said to contain $\beta$-sitosterol as a key constituent.

Key words: Benincasa hispida, Carissa congesta, HPLC, Polyalthia longifolia, $\beta$-sitosterol.

Corresponding author: Dr. Gaurav Mahesh Doshi, Assistant Professor, Department of Pharmacology, Vivekanand Education Society's College of Pharmacy, Mumbai 400074, Maharashtra, INDIA.

Phone No: +91-9819771515

Email: gaurav.pharmacology@gmail.com

DOI : 10.5530/pj.2016.6.15

\section{INTRODUCTION}

In today's scenario, currently much of the phytochemical research is propagated in higher plants and shrubs. Crude plant extracts were initially assayed for their particular phytoconstituents as well as active fractions. The targets are thought to have immense potential in health care system. ${ }^{1}$ The major advantage of the phytochemistry in correlation to HPLC is to carry out the investigation even if the component present in the extract is present in minute amounts. ${ }^{2}$

Benincasa hispida has been stated in Indian system of medicine as Brihatrayee and Bhavaprakasha nighantu. ${ }^{3,4}$ It has been reported to contain proteins, enzymes, vitamin $\mathrm{B}_{1}$ and $\mathrm{C}$, flavonoids, terpenes, phenolic acids, glucose, rhamnose, mannitol, uronic acid as well as trace metals. Sequential extraction and high-speed counter current chromatography have yielded components of peptic polysaccharides and astilbin, catechin and naringenin respectively. ${ }^{5-10}$

In ayurveda, Polyalthia longifolia is well known its preparations such as Kula, Sitaphala kula, Kaphapitashama, Anulomak, Krimighna, Pramehahara and many other allied remedies. ${ }^{11-13}$ Various constituents have been identified from the leaves like as azafluorene and Aporphine $N$-oxide alkaloids. ${ }^{14} \mathrm{PL}$ has been reported for the presence of flavonoids and other associated constituents such as quercetin-3-o- $\beta$-glucopyranoside, kaemperfol-3-o- $\alpha$-rhamnopyranosyl- $\beta$-glucopyranoside and kaempferol3-o- $\alpha$-rhamnopyranosyl-(1-6) $\beta$ gluco pyranoside. ${ }^{15}$ Ethanolic extract has showed the presence of triterpenoids components. ${ }^{10}$

Carissa congesta is well known as Bengal currant, Christ's thorn, Karaunda. ${ }^{16}$ The roots have yielded volatile components such as 2-acetylphenol, lignans like carinol and mixtures of sesquiterpenes as carissone and carindone. In addition, Des- $n$-methylnoracronycine and lupeol have been reported..$^{17-20}$
Though numbers of researchers have scrutinized presence of $\beta$-sitosterol by various chromatographic techniques, no studies on HPLC reported to guide fractions for $\beta$-sitosterol from these plant extracts. $\beta$-sitosterol has been reported to enhance the in vitro proliferative activity of T-lymphocytes and to act as chemopreventive agent in colon and breast cancer. ${ }^{21,22}$ Taking snapshot of above lookouts, our research article focuses on estimation of $\beta$-sitosterol estimation in the petroleum ether extracts of $\mathrm{BH}$ seeds and $\mathrm{CC}$ roots and ethanolic extract of PL leaves ethanolic extract by one of the most precise and sensitive method i.e. HPLC.

\section{EXPERIMENTAL}

\section{Part A: Collection, authentication and extraction}

All the studies undertaken in Part A have been previous been reported by us when we subjected our extracts to Thin Layer Chromatography (TLC) and High Performance Thin Layer Chromatography (HPTLC). ${ }^{10,23-25}$

\section{Part B: Reagents and Biomarker}

Standard biomarker of $\beta$-sitosterol was procured from Sigma-Aldrich Private Ltd., Bangalore, India, and solvents from Merck Ltd., Mumbai, India.

\section{Part C: Instrumentation}

- Chemicals: $\beta$-sitosterol Standard, buffers, ethanol, plant extracts of $\mathrm{PL}, \mathrm{BH}$ and $\mathrm{CC}$ were used for the study.

- HPLC instrument make: Shimadzu LC-10 ATVP

- Software: Chromtech N 2000 data

- Detector: UV Wavelength $254 \mathrm{~nm}$.

- Flowrate: $1 \mathrm{ml} / \mathrm{min}$

- Injection volume: $20 \mu \mathrm{l}$ 
Table 1: HPLC analysis of Benincasa hispida, Carissa congesta, Polyalthia longifolia and standard $\beta$-sitosterol

\begin{tabular}{ccc}
\hline Details of standard and sample & Observation Parameter (Ret Time) Area & $\%$ of $\beta$-sitosterol \\
\hline BH extract & $(2.369) 1232761$ & $36.00 \% \mathrm{w} / \mathrm{v}$ \\
CC extract & $(2.416) 255510$ & $7.46 \% \mathrm{w} / \mathrm{v}$ \\
PL extract & $(2.375) 109900$ & $3.21 \% \mathrm{w} / \mathrm{v}$ \\
Standard $\beta$-sitosterol & $(2.378) 3081902$ & \\
Dilution ratio (standard: sample) & $1: 1$ & \\
\hline
\end{tabular}
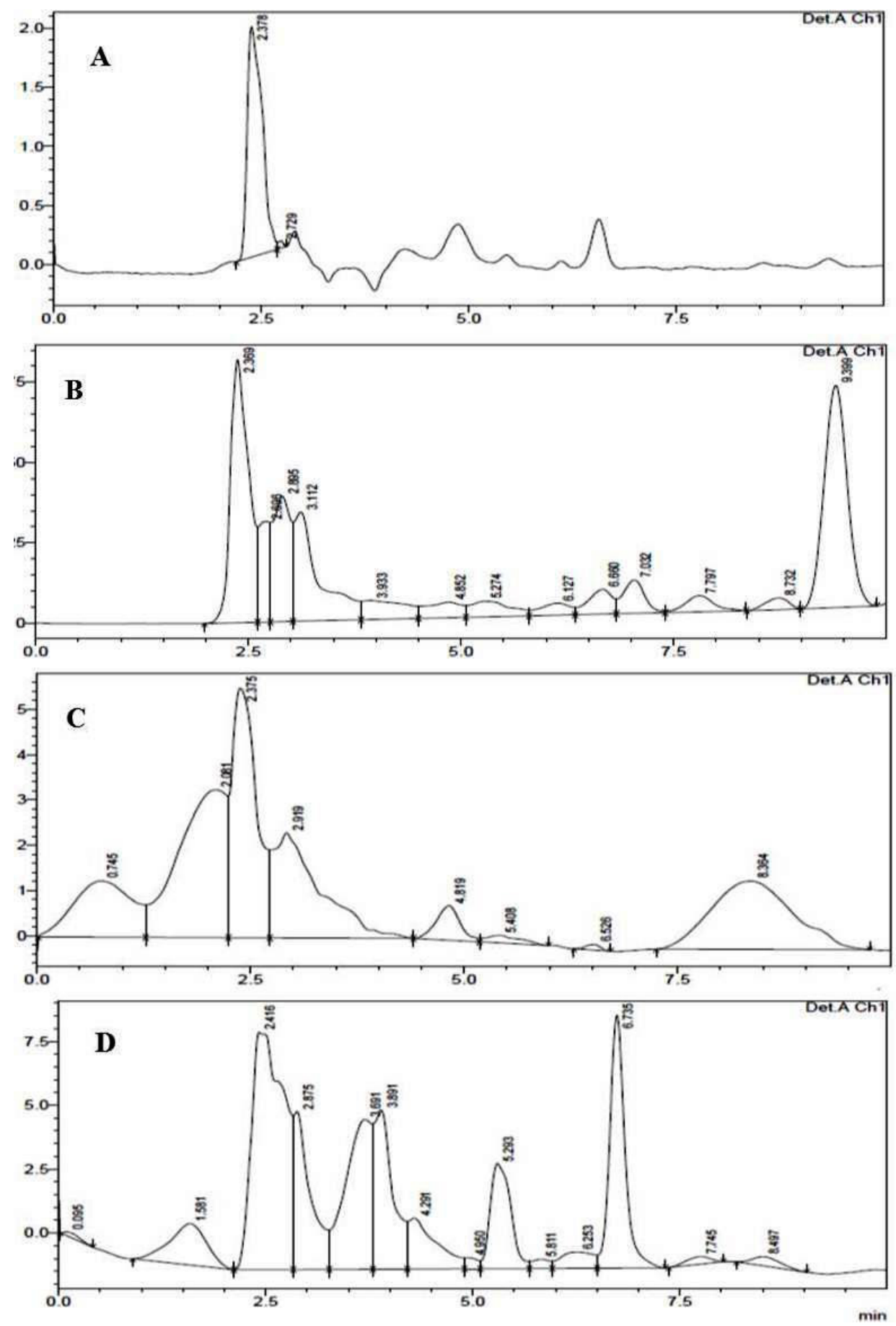

Figure 1: HPLC peaks of standard $\beta$-sitosterol (A), Polyalthia longifolia leaves (B), Benincasa hispida seeds (C) and Carissa congesta roots (D). 
- Column dimensions: RP C-18, $250 \times 4.6 \mathrm{~mm}, 5 \mu$

\section{MATERIALS AND METHODS}

In the current research article, our studies focuses on HPLC were done after we have reported identification of $\beta$-sitosterol in our previous studies by TLC and HPTLC. ${ }^{24-26}$ The procedure comprises of Methanol: Phosphate Buffer ( $\mathrm{pH} 3$ ) as mobile phase in ratio 70:30. $2 \mathrm{mg}$ of standard and $5 \mathrm{mg}$ of the sample were dissolved in $2 \mathrm{ml}$ and $5 \mathrm{ml}$ of solvent respectively. The formula used was:

Percentage of $\mathbf{b}-$ sitosterol $=\frac{\text { sample area 'standard ' purity }}{\text { standard area' sample dilution' } 100}{ }^{\prime} 100$

\section{RESULTS}

\section{(a) Extraction and preliminary phytochemical analysis}

The results of extraction yield, preliminary analysis of the extracts, TLC and HPTLC of $\beta$-sitosterol were been previously reported by us. ${ }^{23-25}$

\section{(b) High Performance Liquid Chromatography (HPLC)}

The ethanolic extract of PL leaves and the petroleum ether extracts of $\mathrm{BH}$ seeds and CC roots have shown well-resolved peaks at $254 \mathrm{~nm}$. Retention time of the extract was observed to be $2.3 \mathrm{~min}$ in comparison to standard $\beta$-sitosterol at a flow rate of $1 \mathrm{ml} / \mathrm{min}$. (Tables 1 and Figure 1 (A, B, C and D).

\section{DISCUSSION}

Plant extracts has shown the presence of various phytoconstituents identified by chromatographic techniques which are therapeutically and economically important. Chromatography has been regarded as one of the best tool in terms of separation of phytoconstituents by subjecting the extracts to analytical method development. ${ }^{2}$

HPLC is one of the most sensitive as well as powerful visualization technique preferred in the detection of the multiple phytoconstituents present in plant extracts due to its sensitivity, accuracy and precision. The analytical technique is selected as it is specific and solution stable, provides linearity of 0.98 and $99.20 \%$ of sample. ${ }^{26}$ Thus, the results depicted in this research have provided us with a probable confirmation of $\beta$-sitosterol, which we had identified previously by HPTLC.

\section{CONCLUSION}

Our current research studies direct the field of pharmacognosy researchers and herbal scientists towards $\beta$-sitosterol constituent identified from $\mathrm{BH}$, PL and CC extracts by HPLC.

\section{ACKNOWLEDGEMENT}

We would like to acknowledge the college management who provided us all the facilities to do this work.

\section{CONFLICT OF INTEREST}

We declare no conflict of Interest.

\section{ABBREVIATION USED}

BH: Benincasa hispida; CC: Carissa congesta; PL: Polyalthia longifolia; HPLC: High Performance Liquid Chromatography.

\section{REFERENCES}

1. Hostettmann K. (ed.) Methods in Plant Biochemistry, Vol.6, Academic Press, London 1991.

2. Harborne JB. Phytochemical methods: A guide to modern techniques of Plant analysis, First Indian Reprint, Springer Publication House; 2005.1-295.

3. Anonymous. In: The Wealth of India: A Dictionary of Indian Raw materials and Industrial parts. Raw Materials Published by Council of Scientific \& Industrial Research. 1948;1(173):82-5

4. Pagare, MP, Pati L, Kadam VJ. Benincasa hispida: A Natural medicine. Research Journal of Pharmaceutical Technology. 2011;4(12):1941-5.

5. Mandana B, Rahman AR, Farah ST, Mohd AN, Zaidul IS, Ali G. Optimization of Ultrasound-Assisted Extraction of Crude Oil from Winter Melon (Benincasa hispida) Seed Using Response Surface Methodology and Evaluation of its Antioxidant Activity, Total Phenolic Content and Fatty Acid Composition. Molecules. 2012;17(10):11748-62.

6. Mazumder S, Morvan C, Thakur S, Ray B. Cell Wall Polysaccharides from Chalk umra (Benincasa hispida) Fruit. Part I. Isolation and Characterization of Pectins. Journal of Agricultural Food Chemistry. 2004;52(11):3556-2.

7. Latifah KD. Bioactive Proteins from Benincasa hispida (Thunb.) Cogn. Hayati Journal of Biosciences. 2009;16(4):161-4.

8. Ghosh K, Baghel MS. A Pharmacognostical and Physiochemical study of Benincasa hispida with Ayurvedic Review. International Journal of Research and Ayurvedic Pharmacy. 2011;2(6):1664-8.

9. Du Q, Qi Z, Ito Y. Isolation and Identification of Phenolic Compounds in the Fruit of Benincasa hispida by HSCCC. Journal of Liquid Chromatography and Related Techniques. 2005;28(1):137-44.

10. Doshi GM, Chaskar PR, Une HD. Elucidation of $\beta$-sitosterol from Benincasa hispida Seeds, Carissa congesta Roots and Polyalthia longifolia leaves by High Performance Thin Layer Chromatography. Pharmacognosy Journal. 2015:7(4):221227.

11. Warrier PK, Nambiar VP, Ramankutty C. In: Indian Medicinal Plants: A compendium of 500 species. Vol. 4. Chennai, India: Orient Longman Private Limited; 1994 p. 330-2.

12. Anonymous. In: The Wealth of India: A dictionary of Indian Raw materials and Industrial parts. Vol. 2. Raw Materials Published by Council of Scientific and Industrial Research. 1950. p. 82-7.

13. Anonymous. In: The Wealth of India: A dictionary of Indian Raw materials and Industrial parts. Vol. 2. Raw Materials Published by Council of Scientific and Industrial Research. 1950. p. 186-8.

14. Sampath M, Vasanthi M. Isolation, structural elucidation of flavonoids from Polyalthia longifolia (Sonn.) Thawaites and evaluation of antibacterial, antioxidant and anticancer potential. International Journal of Pharmacy and Pharmaceutical Sciences. 2013;5(1):336-41.

15. Sashidhara KV, Singh SP, Srivastava A, Puri A. Identification of the antioxidant principles of Polyalthia longifolia var. pendulum using TEAC assays. Natural Products Research. 2011;25(9):918-26.

16. Anonymous. In: The Wealth of India: A dictionary of Indian Raw materials and Industrial parts. Raw Materials Published by Council of Scientific and Industrial Research. 1950; II: 82 \& 186-8.

17. Warrier PK, NambiarVPK, Ramankutty C. In: Indian Medicinal Plants: A compendium of 500 species. Published by Orient Longman Private Limited. 1994; I: 386-9.

18. Kubola J, Siriamorpun S, Meso N. Phtochemicals, Vitamin C and Sugar content of Thai wild fruits. Food Chemistry. 2011;126(3):972-81.

19. Devmurari K, Shivanand P, Jivani P. A Review on Carrisa Congesta: Phytochemical Constuients, Traditional Use and Pharmacological Properties. International Journal of Chemical Sciences. 2010;8(1):81-7.

20. Ganapaty S, Bharath C, Laatsch H. Des-N-Methylnoracronycine from the roots of Carissa Congesta. Wight. International Journal of Green Pharmacy. 2010;4(3):186-8

21. Gallo MBC, Sarachine MC. Biological Activities of $\beta$-sitosterol. International Journal of Pharmaceutical and Biomedical Sciences. 2009;3(1):46-62.

22. Oliveria EMS, Freitas SL, Martins FS, Couto RO, Pinto MV, Paula JR. Isolation and quantitative HPLC-PDA analysis of $\beta$-sitosterol in phytopharmaceutical intermediate products from Vernonanthura ferruginea (Less.). Quim Nova. 2012;35(5):1041.

23. Doshi GM, Une HD. Chromatographic studies on Benincasa hispida (thunb.) Cogn Seed extract scrutinized by HPLC and HPTLC. Pharmacognosy Journal. 2014;6(3):42-8.

24. Doshi GM, Chaskar PR, Zine SP, Une HD. Cold Extraction of Carissa congesta Wight monitored by a comparative revision of HPLC and HPTLC. Pharmacognosy Communications. 2014;4(2):29-33.

25. Doshi GM. Chaskar PK. Zine SP Une HD. Solicitation of HPLC and HPTLC for determination of rutin from Polyalthia longifolia. Pharmacognosy Research. 2014;2(1):29-33

26. Nagore DH, Patil PS, Kuber VK. Comparison between High Performance Liquid Chromatography \& High Performance Thin Layer Chromatography for determination of Diosgenin from the fenugreek seeds. International Journal of Green Pharmacy. 2012;6(4):315-20. 


\section{PICTORIAL ABSTRACT}

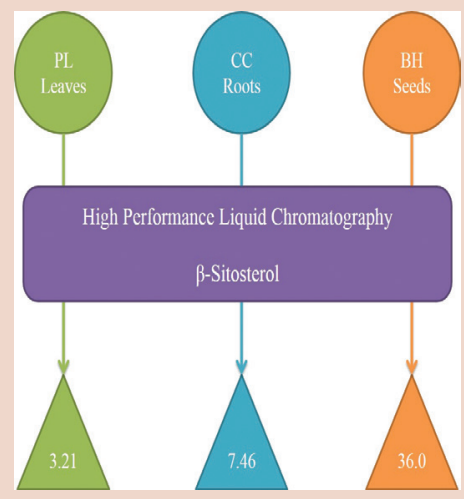

\section{SUMMARY}

- The paper covers estimation of $\beta$-sitosterol present in the $\mathrm{BH}$ seeds, $\mathrm{CC}$ roots and PL leaves extracts by High Performance Thin Layer Chromatography.

- They were found to be $36.00,7.46$ and $3.21 \% \mathrm{w} / \mathrm{w}$ at $254 \mathrm{~nm}$ respectively.

- Thus, extracts contains a key constituent such as $\beta$-sitosterol.

\section{ABOUT AUTHORS}

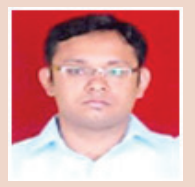

Dr. Gaurav M. Doshi: Presently working as Assistant Professor, Department of Pharmacology, Vivekanand Education Society's College of Pharmacy, Chembur (East), Mumbai- 400074. He has 34 journal papers; 85 citations to his credit. He has completed Ph.D from Department of Pharmaceutical Sciences, Pacific Academy of Higher Education and Research University, Udaipur, Rajasthan, India in 2016.

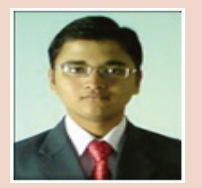

Mr. Pratip K Chaskar: Presently working as Assistant Professor, Department of Pharmaceutical Chemistry, Vivekanand Education Society's College of Pharmacy, Chembur (East), Mumbai- 400074. He has 14 journal papers; 44 citations to his credit.

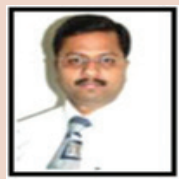

Dr. Hemant D Une: Working as Associate Professor, Vice- Principal and Head of Department of Pharmacology and Post Graduation, Y. B. Chavan College of Pharmacy, Rouzabagh, Aurangabad, Maharashtra, India. He has 26 journal papers; 107 citations to his credit. 